\title{
Seeing Red: The Female Body and Periodic Renewal
}

\author{
Diana York Blaine
}

The Bleeding of America: Menstruation as Symbolic Economy in Pynchon, Faulkner, and Morrison, by Dana Medoro. Westport, CT: Greenwood, 2002. 184 pp. $\$ 61.95$.

Alice Cooper once said that "only women bleed," but according to Dana Medoro, so do many of the canonical texts of American literature. And much as women and men in general have been taught to shun mention of the monthly "curse," male and female critics alike have largely avoided any discussion of the importance of menstruation in these works, despite their authors' best intentions: "Stanley Koteks" is hardly a subtle moniker, after all. But little of the previous criticism on Pynchon, Faulkner and Morrison investigates the paradigm, or indeed identifies it as one, even though, Medoro convincingly argues in The Bleeding of America, an entire parallel universe in these authors' novels revolves around the female body, the moon and menses, and offers an alternative to the masculine culture of separation, aggression and murder that each of these socially conscious authors indicts.

Which means that this is a really important book.

Blood matters, Medoro demonstrates: to the Puritans, whose jeremiads run with it; to the American authors who followed them, in scenes of devastation from our Civil and World Wars; and to critics and theorists, who trace the tracks of blood in both fictional texts and cultural rituals. Medoro seeks in this ambitious work to connect the three groups, demonstrating how the trope of pollution and renewal that functioned so seminally in the Puritanical vision of the New Jerusalem actually links intimately with gendered understandings of the female body and its often tabooed role in regeneration. This body, she shows, subsequently appears in works of American fiction and can be trenchantly explicated through the ancient cosmology of menses.

Like the best pieces of scholarship I have encountered, this book has permanently altered my perception of the canon. At the same time it has left me wondering how I could have overlooked what Medoro reveals: novels dripping with a type of reproductive blood that disturbs our pat binaries of self and other, purity and pollution, sacred and profane. The presence of menstruating women, and more crucially their 
centrality to the narratives, might be described as obvious; yet until I read The Bleeding of America, they remained invisible to me. 1 think the reason is a simple one that speaks to the need for feminist scholarship such as Medoro's: our paradigms are so insistently patriarchal that we are in effect ideologically proscribed from seeing alternative visions until groundbreaking works come along to change them.

Medoro canvasses much male scholarship on the Puritans, finding that it desperately back-pedals from the very material it deals with: the eroticized, reviled, enticing and often bleeding female body. Sacvan Bercovitch, for instance, goes so far as to deny interest in the female sexuality pervading Puritanical myths even as "his examples and terminology invoke and reproduce it" (Medoro 5). As Judith Fetterley observes in The Resisting Reader, we learn to read as men-males and females alike - and so we learn to deny our connection to the female body and the larger cultural implications of sexism.

The sources of this rejection of the maternal can be traced to our Puritan forebears, who, as Medoro notes, loathed their connection to the female body and sought purification from it through a man. Cotton Mather thundered that "we are borne in the gore blood of sinfull defilements, and therefore God hath provided the blood of Christ, to wash and cleanse us from our Mothers womb'" (qtd. in Medoro 6). This triumphant patriarchal monotheism begins with biblical injunctions against woman and with the illogical assertion of a male creator that displaces earlier cosmologies invoking female deities and menstrual rituals. While these alternative understandings may have become outlawed, they never vanished completely. Medoro traces their presence in the visionary works of three of our most important authors, each of whom in her or his own way invokes the powerful semiotic of menses in order to disturb a culture whose self-righteous theology and legacy of oppression all to often lead away from life and towards an embrace of death.

Medoro draws on a fascinating mélange of theoretical works, including those by Jacques Derrida, Julia Kristeva, René Girard, JeanJoseph Goux and Mircea Eliade. Beginning with Pynchon, whose fiction clearly references Eliade, she charts the ways $V$. "opposes masculine domination through the figure of the menstruating female, whose bleeding body is both curse and cure of patriarchal consolidation" (23). In Lot 49, Medoro reveals, Oedipa Maas also represents an alternative source of knowledge to that represented by the phallus, as her quest and her body reverberate with a waste (W.A.S.T.E.) which offers a sacred form of communication. In Gravity's Rainbow, the rocket signifies a brutal masculine order; Medoro charts an opposing system in the novel-a system based on the sieve, traditionally associated with 
the female - which "ultimately searches for a language that escapes phallic sedimentation" (54).

Her reading of Faulkner's novels similarly reveals a central menstrual signification that previous criticism has ignored or marginalized. Medoro argues that Caddy's role in The Sound and the Fury reverberates precisely because of her bleeding body, which permits her escape from the dying Compson household and the white southern (male) rule it represents. In this reading the tabooed tree in the garden signifies Eve's defiance of the law of the Father and her subsequent monthly reminder of this "fall" from grace. But the fall also incorporates its own renewal, as the mark of menstrual blood speaks of the female capacity to regenerate the species. In this way Caddie becomes pharmakon, both poison and its antidote. While menstrual blood would seem to be an obvious liquid for Derrida to invoke in his discussion of the pharmakon, Medoro notes its conspicuous absence from his list. His silence on the subject of menstrual blood, which Medoro's text defies, parallels its absence from other critical works and, in effect, speaks to the power of, and the powerful taboo against, this material.

Eric Sundquist does analyze menstruation in Light in August, but he stops short of considering the profound ways it suffuses the text. His reading "leaves us wondering what roles Joanna's menopause, Lena's pregnancy, Bobbie's periods, and Milly's bloody death play in the novel's crisis of blood," as he focuses exclusively on racial violence and ignores that against women (Medoro 95). Medoro makes good this lack, and draws an intriguing parallel between Faulkner's and Pynchon's use of the taboo against menstrual blood and its relation to the glorification of war. Both authors, she suggests, view war as the true curse.

According to Medoro, Absalom, Absalom!'s indictment of Sutpen's divisive vision reveals Faulkner's mission to link white-male violence with the evolutionary oppression of women, who viewed each other as competitors only when their blood became "'an economic matter like someone who insists upon installing a counter or a scales or a safe in a store or business'" (qtd. in Medoro 119). She finds in this novel a regenerative vision embodied in the menstruating daughter, whose blood is juxtaposed with that spilled in violence.

The final section of The Bleeding of America covers the works of Toni Morrison, who Medoro believes extends Faulkner's antihierarchical insights. While Faulkner does not claim to speak for the female racial other, Morrison seeks to provide voices for those lost African women whose blood served as fertilizer for the Southern-indeed the American -dynasty. Medoro reads The Bluest Eye as yet another jeremiad, this one an indictment of the African-American community for adopting 
white values. Pecola stands as the scapegoat figure, "sacrificed to the stereotypical image of black women's wild sexuality" that arose out of a racist binary in which only white women could be pure (132).

The discussions of Song of Solomon and Beloved offer sweeping, provocative and inspiring interpretations of these texts as radical links to goddess narratives and menstrual cosmologies. Medoro also gives a final revealing example of the critical ignorance of menstruation's centrality as she analyzes Goux's Symbolic Economies: After Marx and Freud, a work which seeks to excavate an antipatriarchal order running against that of gold and the phallus. This desire leads Goux to imagine a maternal economy with meaning emerging out of a "'wound, gash, cut, stain'" (qtd. in Medoro 153). Given these images, one assumes Goux will invoke menstruation. But instead he "circles around a language of blood without ever landing on the possibility it presents to his argument" (153). Sheesh.

Menstruation and its potential for sacred meaning and for healing may be willfully invisible to mainstream culture (which raised me to fear above all having a betraying stain of red on my garments), but fortunately its regenerative power has not escaped the notice of three of our finest authors, nor, as manifested in The Bleeding of America, the notice of one of our keenest new critics. Medoro not only explicates these texts, as scholars do, but she shares their vision of mutual responsibility and healing, here manifested in the collective social body of woman and its ancient bloody ties to life.

- University of Southern California 